\title{
Metabolism of Sialic Acid in Regenerating Rat liver
}

\author{
Yasushi OKAMOTO and Nobu AKAMATSU* \\ Department of Biochemistry, St. Marianna University. School of Medicine, Takatsu, Kawasaki 213, Japan
}

(Received 23 November 1979)

\begin{abstract}
In regenerating rat liver slices $24 \mathrm{~h}$ after partial hepatectomy, the incorporation of $\mid 1-{ }^{14} \mathrm{C}$ |glucosamine into 'free sialic acid' ( $N$-acetylneuraminic acid + CMP- $N$-acetylneuraminic acid) decreased to below $50 \%$ of the control values and the incorporation into protein-bound sialic acid decreased to the same extent. The incorporation of $\left[{ }^{14} \mathrm{C}\right.$ lglucosamine into 'free sialic acid' decreased during the period from 6 to $47 \mathrm{~h}$ after hepatectomy, showing a minimum at $12 \mathrm{~h}$, and recovered to the control value by $96 \mathrm{~h}$. At $12 \mathrm{~h}$, the activities of UDP- $N$-acetylglucosamine 2-epimerase (UDP-2acetoamido-2-deoxy-D-glucose 2-epimerase, EC 5.1.3.14) and $N$-acyl-D-mannosamine kinase (ATP: 2-acylamino-2-deoxy-D-mannose 6-phosphotransferase, EC 2.7.1.60) in the liver were significantly decreased. The amount of protein-bound sialic acid in the liver was not changed after partial hepatectomy, but the amount in plasma was changed,

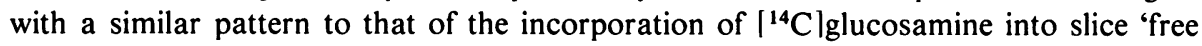
sialic acid'. These results indicate that the synthesis of sialic acid in the liver much decreases in the early stage of the regeneration and that this may be correlated with the decreased synthesis of plasma sialoglycoproteins.
\end{abstract}

During early periods of liver regeneration, an accumulation of UDP- $N$-acetylhexosamine and a low incorporation of $\left[{ }^{14} \mathrm{Clglucosamine}\right.$ into glycoproteins were observed in rat-liver slices (Okamoto \& Akamatsu, 1977). These changes were mainly attributed to the decreased activity of $\mathrm{N}$-acetylglucosamine transfer from UDP- $N$-acetylglucosamine to endogenous acceptors. But it was also observed that the decrease of the activity was less signficant than that of $\left[{ }^{14} \mathrm{C}\right.$ lglucosamine incorporation into glycoproteins within $12 \mathrm{~h}$ after partial hepatectomy (Okamoto et al., 1978).

Since glucosamine is also utilized for synthesis of sialic acid via UDP- $N$-acetylglucosamine (Kornfeld et al., 1964), we studied the activity of sialic acid synthesis in slices and crude extract of liver as well as its correlation with the amount of protein-bound sialic acid in both liver and plasma.

\section{Materials and Methods}

\section{Chemicals}

$N$-Acetyl-D-mannosamine, $\quad N$-acetylneuraminic acid, phosphoenolpyruvate, and ATP were from Sigma. UDP- $N$-acetyl-D-glucosamine was from Boehringer-Mannheim. $N$-Acetyl-D-mannosamine

* To whom reprint requests and correspondence should be addressed. 6-phosphate was prepared from $N$-acetyl-Dmannosamine with $N$-acyl-D-mannosamine kinase (EC 2.7.1.60) which was prepared from rat liver up to the protamine sulphate step of the method of Kundig \& Roseman (1966). The reaction product was applied to a Dowex 1 (X8; formate form; 200-400 mesh) column $(1.2 \mathrm{~cm} \times 30 \mathrm{~cm})$. The column was washed with water. $N$-Acetyl-Dmannosamine 6-phosphate was eluted by $4 \mathrm{M}$-formic acid and lyophilized. The product was dissolved in a small volume of water. The purity was checked by paper chromatography before and after treatment with calf intestine alkaline phosphatase lorthophosphoric-monoester phosphohydrolase (alkaline optimum), EC 3.1.3.1; Miles-Seravac, Holyport Berks., U.K.I. $N$-Acetyl-D-mannosamine 6-phosphate was determined by the method of Reissig et al., (1955) with $N$-acetyl-D-mannosamine as a standard. D$\left[1-{ }^{14} \mathrm{C}\right]$ Glucosamine hydrochloride $(58 \mathrm{Ci} / \mathrm{mol})$ and $\mathrm{N}$-acetyl-D-[U- $\left.{ }^{14} \mathrm{C}\right] \mathrm{mannosamine}(270 \mathrm{Ci} / \mathrm{mol})$ were from The Radiochemical Centre, Amersham, Bucks., U.K. UDP- $N$-acetyl-D-[U-14 C]glucosamine $(235 \mathrm{Ci} / \mathrm{mol})$ was from New England Nuclear, Boston, MA, U.S.A. Other chemicals were of commercial origin.

\section{Animals}

Male Wistar rats (100-120g, Nihon CLEA, 
Tokyo, Japan) were fed ad libitum with laboratory chow in a room at a constant temperature $\left(23.5^{\circ} \mathrm{C}\right)$ with $12 \mathrm{~h}$ each of light $(06.30-18.30 \mathrm{~h})$ and darkness. Partial hepatectomy (Higgins \& Anderson, 1931) was performed between $09.00 \mathrm{~h}$ and $10.00 \mathrm{~h}$ and sham-operated rats were used as controls.

\section{Preparation of liver slices and incubation procedure}

Liver slices were prepared and incubated with D- $\left[1-{ }^{14} \mathrm{C}\right]$ glucosamine as described (Okamoto \& Akamatsu, 1977).

Preparation of acid-soluble and acid-insoluble fractions

The acid-soluble and acid-insoluble fractions from the slices and the acid-insoluble fraction from the incubation medium were prepared as reported (Okamoto \& Akamatsu, 1977).

Acid-insoluble fractions of livers and plasma were prepared as follows. Approx. $0.4 \mathrm{~g}$ of liver was homogenized with $10 \mathrm{vol}$. of $0.154 \mathrm{M}-\mathrm{NaCl}$, and 0.5 vol. of ice-cold $30 \%(\mathrm{w} / \mathrm{v})$ trichloroacetic acid was added to the homogenate. Blood (1-2 ml) taken by cardiac puncture was immediately transferred into a tube containing $15 \mathrm{mg}$ of sodium citrate and the plasma was obtained by centrifugation at $1000 \mathrm{~g}$ for $10 \mathrm{~min}$. Ice-cold $10 \%(\mathrm{w} / \mathrm{v})$ trichloroacetic acid $(4 \mathrm{ml})$ was added to $0.2 \mathrm{ml}$ of the plasma. Both samples were cooled in ice for $20 \mathrm{~min}$, centrifuged at $1000 \mathrm{~g}$ for $10 \mathrm{~min}$ and the precipitates were washed once with chloroform/methanol/ diethyl ether $(2: 1: 1$, by vol.), twice with $95 \%(v / v)$ ethanol, and then were dried under reduced pressure.

Separation and determination of sialic acid from acid-soluble and acid-insoluble fractions

Trichloroacetic acid was extracted from the acidsoluble fraction with diethyl ether. The fraction was adjusted to $\mathrm{pH} 8$ with $0.5 \mathrm{M}-\mathrm{NH}_{4} \mathrm{OH}$, applied to a Dowex 1 (X8; formate form; 200-400 mesh) column $(0.6 \mathrm{~cm} \times 13 \mathrm{~cm})$ and eluted with $50 \mathrm{ml}$ of $0.01 \mathrm{M}$-formic acid followed by $25 \mathrm{ml}$ of $1 \mathrm{M}$-formic acid. The latter fractions contained 'free sialic acid' (free $N$-acetylneuraminic acid and $N$-acetylneuraminic acid derived from CMP- $N$-acetylneuraminic acid) (Okamoto \& Akamatsu, 1977).

The acid-insoluble fraction was suspended in $5 \%(\mathrm{w} / \mathrm{v})$ trichloroacetic acid at a protein concentration of $15 \mathrm{mg} / \mathrm{ml}$ or less and was hydrolysed at $80^{\circ} \mathrm{C}$ for $1 \mathrm{~h}$ (Molnar et al., 1965). Afiter centrifugation, trichloroacetic acid was extracted from the supernatant with diethyl ether. The supernatant was adjusted to $\mathrm{pH} 8$ and sialic acid (derived from protein-bound sialic acid) was separated by column chromatography, as described for the acid-soluble fraction.

The fractions that contained sialic acid were evaporated at $40-50^{\circ} \mathrm{C}$. The residues were dissolved in a small volume of water and sialic acid was determined by the method of Warren (1959) with $\mathrm{N}$-acetylneuraminic acid as a standard. To the radioactive samples, $(1 \mathrm{ml}), 10 \mathrm{ml}$ of $0.6 \% 2,5$ diphenyloxazole in toluene/Triton X-100 (2:1, $\mathrm{v} / \mathrm{v})$ was added. The radioactivity was determined by using a Beckman LS-100 liquid-scintillation counter.

\section{Determination of protein-bound hexosamine in plasma}

Protein-bound hexosamine was determined as previously reported (Okamoto et al., 1978) in the residues of the hydrolysate of the plasma acidinsoluble fraction.

\section{Enzyme assays}

Livers were homogenized with 9 vol. of $0.154 \mathrm{M}^{-}$ $\mathrm{KCl}$ containing $10 \mathrm{mM}$-potassium phosphate buffer (pH 7.6), $5 \mathrm{~mm}$-EDTA and $2 \mathrm{~mm}$-dithiothreitol in a Potter-Elvehjem homogenizer with a Teflon pestle. The homogenate was centrifuged at $10000 \mathrm{~g}$ for $10 \mathrm{~min}$ and the supernatant was centrifuged again at $105000 \mathrm{~g}$ for $1 \mathrm{~h}$. The post-microsomal supernatant was used as the crude extract. The activity of UDP- $\mathrm{N}$-acetylglucosamine 2-epimerase (UDP-2acetamido-2-deoxy-D-glucose 2-epimerase, EC 5.1.3.14) was assayed essentially by the method of Spivak \& Roseman (1966). The reaction mixture contained the following components in a final vol. of $0.4 \mathrm{ml}: 0.2 \mathrm{M}$-Tris $/ \mathrm{HCl}$ buffer $(\mathrm{pH} 7.5), 2 \mathrm{~mm}$ UDP- $N$-acetyl-D-glucosamine, $50 \mathrm{mM}-\mathrm{MgSO}_{4}$ and $0.1 \mathrm{ml}$ of the liver extract. After incubation at $37^{\circ} \mathrm{C}$ for $30 \mathrm{~min}$, the reaction was stopped by heating the mixture at $100^{\circ} \mathrm{C}$ for $2 \mathrm{~min}$. To the reaction tube was added $180-220 \mathrm{mg}$ of dried Dowex 1 (X8; formate form; 200-400 mesh) resin and $0.6 \mathrm{ml}$ of water. The tube was shaken and was allowed to stand for $5 \mathrm{~min}$. After centrifugation, $\mathrm{N}$-acetyl-D-mannosamine in the supernatant was determined by the method of Reissig et al. (1955) with $N$-acetyl-D-mannosamine as a standard.

The $N$-acyl-D-mannosamine kinase (ATP: 2acylamino-2-deoxy-D-mannose 6-phosphotransferase, EC 2.7.1.60) activity was assayed as described below. The reaction mixture contained the following components in a final vol. of $0.5 \mathrm{ml}: 0.1 \mathrm{M}-\mathrm{Tris} / \mathrm{HCl}$ buffer (pH 8.1), $8 \mathrm{~mm}-\mathrm{N}$-acetyl- $\left|\mathrm{U}-{ }^{14} \mathrm{C}\right|$ mannosamine $(0.27 \mathrm{Ci} / \mathrm{mol}), 12 \mathrm{~mm}-\mathrm{ATP}, 10 \mathrm{~mm}-\mathrm{MgCl}_{2}, 24 \mathrm{~mm}$ $\mathrm{NaF}$ and $0.05 \mathrm{ml}$ of the liver extract. After incubation at $37^{\circ} \mathrm{C}$ for $20 \mathrm{~min}$, the tube was heated at $100^{\circ} \mathrm{C}$ for $2 \mathrm{~min}$ and was then centrifuged at $1000 \mathrm{~g}$ for $10 \mathrm{~min}$. The supernatant was applied to a Dowex 1 (X8; formate form; 200-400 mesh) column $(0.6 \mathrm{~cm} \times 3.6 \mathrm{~cm})$. The column was washed with $8 \mathrm{ml}$ of water. $N$-Acetylhexosamine 6 -phosphate was eluted with $12 \mathrm{ml}$ of $4 \mathrm{M}$-formic acid and 
evaporated. The residue was dissolved in $1.5 \mathrm{ml}$ of water and an aliquot $(0.5 \mathrm{ml})$ was treated with $5-6$ units of alkaline phosphatase in $1.0 \mathrm{ml}$ of $0.1 \mathrm{M}-\mathrm{Tris} / \mathrm{HCl}$ buffer $(\mathrm{pH} 8.5)$ containing $2 \mathrm{mM}$ $\mathrm{MgCl}_{2}$ at $37^{\circ} \mathrm{C}$ for $18 \mathrm{~h}$. (One unit of alkaline phosphatase is the amount of the enzyme catalysing the liberation of one $\mu \mathrm{mol}$ of $p$-nitrophenol from $p$-nitrophenyl phosphate/min at $\mathrm{pH} 10.25$ and $37^{\circ} \mathrm{C}$.) Then the mixture was deionized by passing it successively through columns of Dowex $50 \mathrm{~W}$ $\left(\mathrm{X} 8 ; \mathrm{H}^{+}\right.$form; $200-400$ mesh) and Dowex 1 (X8; formate form; 200-400 mesh). The eluate was evaporated to dryness and dissolved in a small volume of water. A portion was spotted on borate-treated paper (Cardini \& Leloir, 1957; Toyo no. 51). $N$-Acetylmannosamine was separated from $N$-acetylglucosamine by descending paper chromatography with a solvent system of butan-1-ol/ pyridine/water $(6: 4: 3$, by vol.). The area containing $\mathrm{N}$-acetylmannosamine was cut out and the radioactivity was measured in $10 \mathrm{ml}$ of $0.6 \% 2,5$ diphenyloxazole in toluene. The activity of $N$-acylneuraminate-9-phosphate synthase [ $N$-acylneuraminate-9-phosphate pyruvate-lyase (pyruvate-phosphorylating), EC 4.1.3.20l was assayed essentially by the method of Watson et al. (1966). The reaction mixture contained the following components in a final vol. of $0.5 \mathrm{ml}: 0.1 \mathrm{M}$-Tris/ $\mathrm{HCl}$ buffer $(\mathrm{pH} 7.8)$, $2 \mathrm{mM}-\mathrm{N}$-acetyl-D-mannosamine 6 -phosphate, $2 \mathrm{mM}$ phosphoenolpyruvate, $20 \mathrm{~mm}-\mathrm{MgCl}_{2}, 4 \mathrm{~mm}$-dithiothreitol and $0.1 \mathrm{ml}$ of the liver extract. The mixture was incubated at $37^{\circ} \mathrm{C}$ for $30 \mathrm{~min}$, then heated at $100^{\circ} \mathrm{C}$ for $2 \mathrm{~min}$. After centrifugation, the supernatant was used for the assay of $N$-acetylneuraminic acid 9-phosphate by the method of Warren (1959) with $N$-acetylneuraminic acid as a standard.

\section{Determination of protein}

Protein was determined by the method of Lowry et al. (1951) with bovine serum albumin as a standard.

\section{Results}

Time course of $\left[{ }^{14} \mathrm{C}\right.$ lglucosamine incorporation into 'free' and protein-bound sialic acid

In regenerating liver slices and controls at $24 \mathrm{~h}$ after the operation, the incorporation of $\left[{ }^{14} \mathrm{C}\right]$ glucosamine into 'free sialic acid' increased at nearly constant rates up to $120 \mathrm{~min}$ (Fig. 1a). The incorporation into protein-bound sialic acid in the slices increased after a lag of $30 \mathrm{~min}$ and exceeded the incorporation into 'free sialic acid' at $120 \mathrm{~min}$ (Fig. 1b). Uptake into protein-bound sialic acid of the medium rapidly increased after $60 \mathrm{~min}$ (Fig. 1c). These patterns of uptake indicate that the radioactivity taken up first into 'free sialic acid' was transferred to glycoproteins and then released
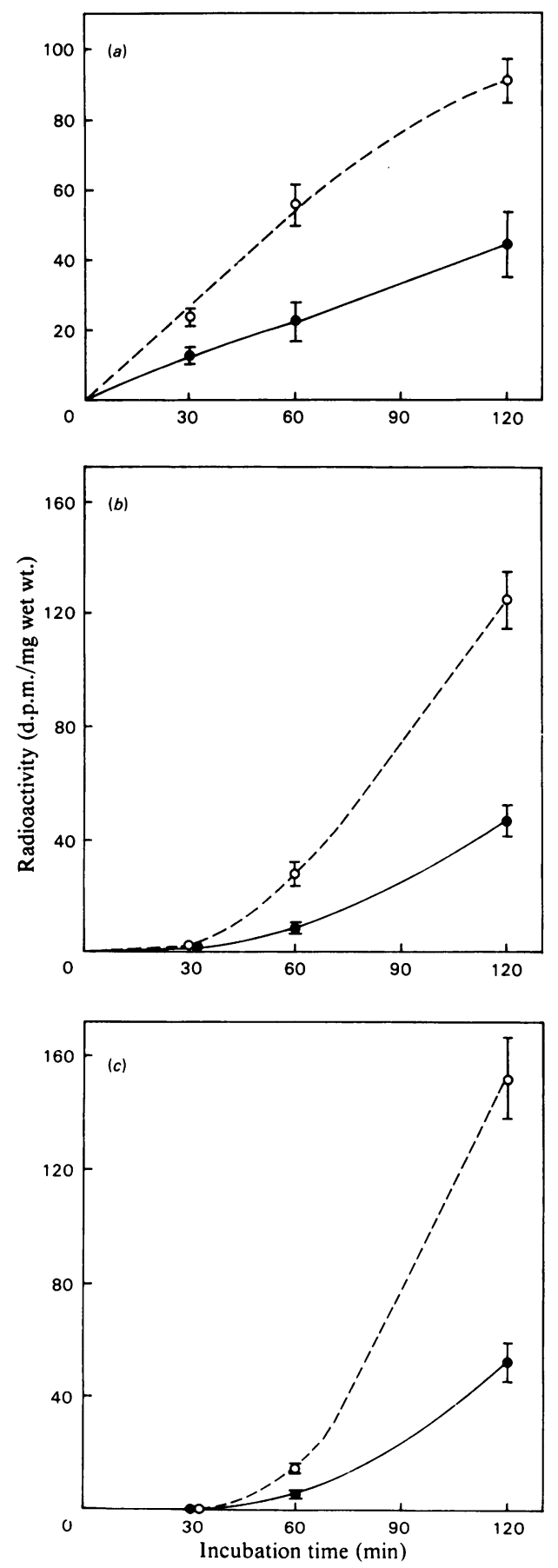

Fig. 1. Time course of $\left[{ }^{14} \mathrm{Clglucosamine}\right.$ incorporation into (a) 'free sialic acid' of slices, $(b)$ protein-bound sialic acid of slices and $(c)$ protein-bound sialic acid of medium

Liver slices (about $200 \mathrm{mg}$ each) prepared from rats at $24 \mathrm{~h}$ after partial hepatectomy or sham operation were incubated with $0.5 \mu \mathrm{Ci}$ of $\left[1-{ }^{14} \mathrm{C} \mid\right.$ glucosamine. O. Controls: 0, regenerating liver. Each point represents the mean \pm S.E.M. for five animals. 
into the medium. In the regenerating liver, the assimilation of $\left[{ }^{14} \mathrm{C}\right.$ lglucosamine into 'free sialic acid' was lower than in the control, and the incorporation into protein-bound sialic acid in the slices and the medium was also decreased to the same extent. These results suggest that the rate of synthesis of 'free sialic acid' in the liver may restrict the amount of sialic acid transferred to glycoproteins at $24 \mathrm{~h}$ after partial hepatectomy.

Changes in $\left[{ }^{14} \mathrm{C}\right.$ lglucosamine incorporation into 'free sialic acid' during liver regeneration

The decreased incorporation of $\left[{ }^{14} \mathrm{C} \mid g l u c o s a m i n e\right.$ into 'free sialic acid' was already significant at $6 \mathrm{~h}$ after partial hepatectomy, reached the lowest value ( $20 \%$ of the control) at $12 \mathrm{~h}$ and continued up to $48 \mathrm{~h}$. Then, the incorporation returned to the control value at $96 \mathrm{~h}$ (Fig. 2). These decreased values may be due to the decreased synthesis of sialic acid. Thus the enzyme activities that participate in the synthesis of sialic acid were assayed at $12 \mathrm{~h}$ after the operation.

\section{Enzyme activities of sialic acid synthesis}

UDP- $N$-acetylglucosamine 2-epimerase, which has been shown to play a regulatory role in sialic acid synthesis (Kornfeld et al., 1964), catalyses the formation of $N$-acetyl-D-mannosamine. $N$-Acetyl-Dmannosamine is converted via $N$-acetyl-D-mannosamine 6-phosphate to $\mathrm{N}$-acetylneuraminic acid 9-phosphate by $N$-acyl-D-mannosamine kinase and
$N$-acylneuraminate 9-phosphate synthase respectively. Accordingly, the activities of these three enzymes were assayed at $12 \mathrm{~h}$. They were all localized in the $105000 \mathrm{~g}$ supernatant (data not shown). Under the assay conditions described above, the formation of the reaction products was linear with respect to time and amounts of enzyme proteins.

In the assay of UDP- $N$-acetylglucosamine 2epimerase activity, the possibility of the formation of $\mathrm{N}$-acetyl-D-glucosamine via $\mathrm{N}$-acetyl-D-glucosamine 1-phosphate from UDP- $N$-acetyl-D-glucosamine by UDP-acetylglucosamine pyrophosphatase and phosphatase and/or from $N$-acetyl-Dmannosamine by $N$-acylglucosamine 2 -epimerase (2-acylamido-2-deoxy-D-glucose-2-epimerase, EC 5.1.3.8; Datta, 1970) was checked. The composition of the reaction mixture was the same as in the UDP- $N$-acetylglucosamine 2-epimerase assay except that $2 \mathrm{~mm}$-UDP- $N$-acetyl-D- $\left[\mathrm{U}-{ }^{14} \mathrm{C} \mid\right.$ glucosamine $(0.125 \mathrm{Ci} / \mathrm{mol})$ was used. The supernatant that was obtained after the treatment with Dowex 1 resin was evaporated and dissolved in a small volume of water. The separation of $\mathrm{N}$-acetyl-Dglucosamine and $N$-acetyl-D-mannosamine by paper chromatography and determination of the radioactivity were as described for the $N$-acylmannosamine kinase assay. $N$-Acetyl-D-mannosamine was only $3-4 \%$ of $N$-acetyl-D-mannosamine in both control and regenerating livers.

In the regenerating liver, the activities of UDP-

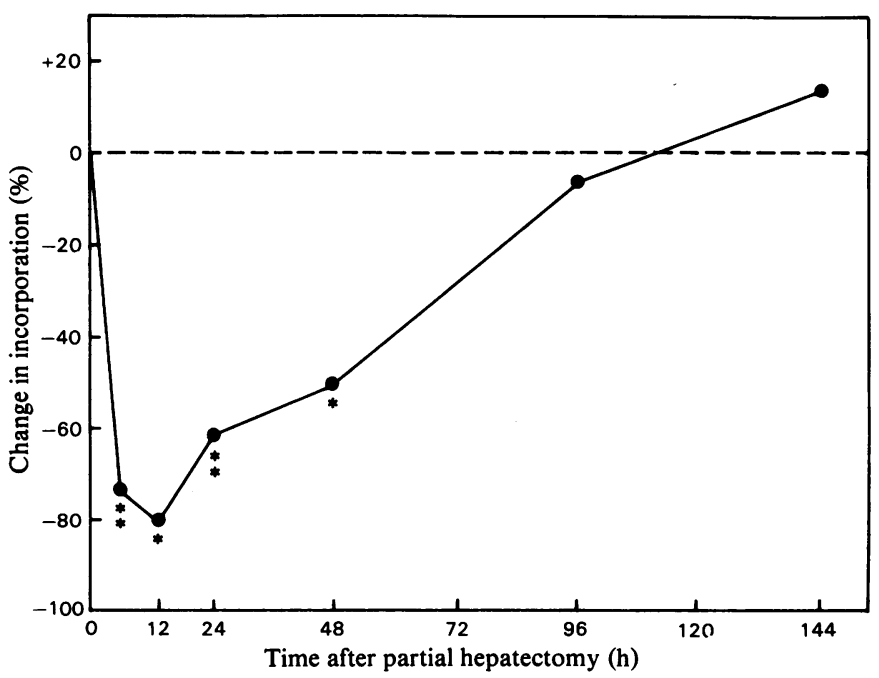

Fig. 2. Changes in $\mid{ }^{14} \mathrm{C}$ lglucosamine incorporation into 'free sialic acid' during liver regeneration Liver slices (about $200 \mathrm{mg}$ each) were incubated with $0.5 \mu \mathrm{Ci}$ of $\left[1-{ }^{14} \mathrm{C}\right.$ lglucosamine for $1 \mathrm{~h}$. The incorporation into regenerating livers is expressed as the differences from controls. The mean values of three to five each of hepatectomized and control rats were used for calculation at each time point. ${ }^{*}$ The differences from controls are statistically significant $(P<0.05){ }^{* *}$, the differences from controls are statistically significant $(P<0.01)$. 
Table 1. Activities of UDP-N-acetylglucosamine 2-epimerase, N-acylmannosamine kinase and N-acylneutraminate 9-phosphate sinthase

Cytosol ( $105000 \mathrm{~g}$ supernatant) fractions were prepared from rat livers $12 \mathrm{~h}$ after partial hepatectomy and sham operation and were used for the assay of the enzyme activities. One unit is defined as the amount of enzyme that catalysed the formation of $1 \mathrm{nmol}$ of product $/ 30 \mathrm{~min}$. Each value represents the mean \pm S.E.M. for four to seven animals. ${ }^{*} P<0.05$ as compared with controls.

Specific activity (units/mg of protein) of

Animals

Controls

Regenerating livers

UDP- $N$-acetylglucosamine
2-epimerase

$46.6 \pm 3.1$

$33.6+3.5^{*}$

$N$-Acylmannosamine

$64.1 \pm 4.6$

$40.7+6.3^{*}$
$N$-Acylneuraminate

9-phosphate synthase

$21.2 \pm 0.9$

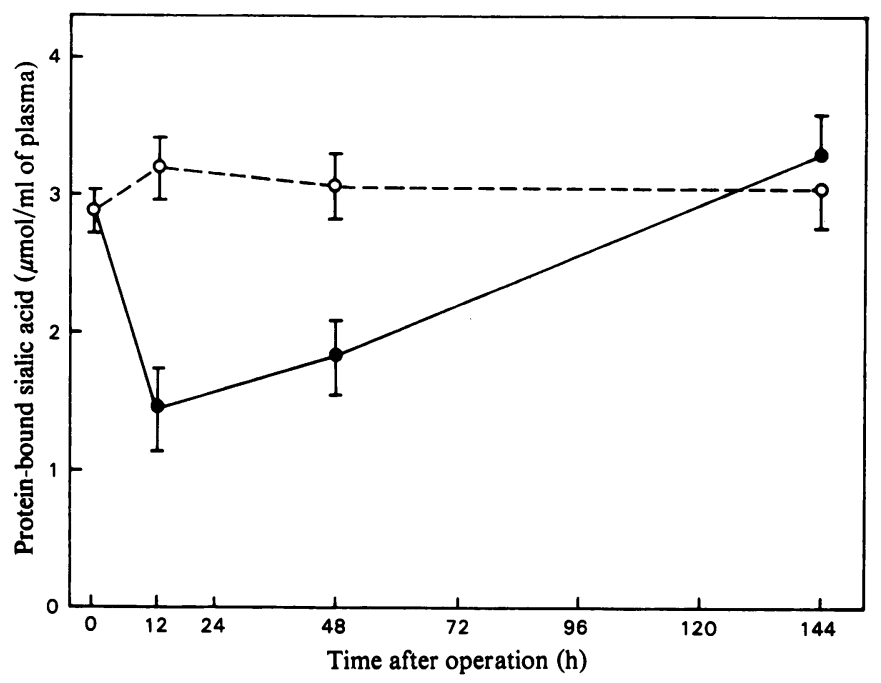

Fig. 3. Concentration of protein-bound sialic acid in plasma at various times after operation Acid-insoluble fractions of plasma were prepared and the concentration of protein-bound sialic acid was determined as described in the Materials and Methods section. $O$, Controls; $\bigcirc$, regenerating livers. Each point represents the mean \pm S.E.M. for three to five animals.

$\mathrm{N}$-acetylglucosamine 2-epimerase and $\mathrm{N}$-acylmannosamine kinase were 72 and $64 \%$ respectively of the control values (Table 1). No significant difference was observed in the activity of $N$ acylneuraminate-9-phosphate synthase. These results indicate that the substantial decrease in sialic acid synthesis is mainly caused by the decreased formation of $\mathrm{N}$-acetyl-D-mannosamine and $\mathrm{N}$ acetyl-D-mannosamine 6-phosphate.

\section{Amount of protein-bound sialic acid in liver and plasma}

The correlation of the decrease in the activity of sialic acid synthesis with the amount of protein- bound sialic acid in vivo was examined. Differences were not observed between the regenerating liver and the control. A similar result was reported by Harms et al. (1973). On the other hand, the amount in plasma was 45 and $60 \%$ respectively of the control at 12 and $48 \mathrm{~h}$ after hepatectomy, then increased and returned to the control level at $144 \mathrm{~h}$ (Fig. 3). The pattern of the changes was very similar to that of the incorporation of $\left[{ }^{14} \mathrm{C}\right]$ glucosamine into liver-slice 'free sialic acid'. The decreased synthesis of sialic acid in liver may be correlated with the decreased incorporation of sialic acid into plasma glycoproteins at early periods of regeneration.

Larmo et al. (1962) reported that the total 
Table 2. Sialic acid and hexosamine contents of plasma proteins

The plasma was taken from rats $12 \mathrm{~h}$ after partial hepatectomy or sham operation. Each value represents the mean \pm S.E.M. for five or six animals. Values in parentheses are percentage differences from controls. ${ }^{*} P<0.05$ as compared with controls.

\begin{tabular}{lcc}
\cline { 2 - 3 } \multicolumn{1}{c}{ Animals } & Sialic acid & Hexosamine \\
Controls & $48.8 \pm 2.7$ & $89.6 \pm 4.1$ \\
Regenerating livers & $29.4 \pm 5.0^{*}$ & $71.9 \pm 6.4^{*}$ \\
& $(-40)$ & $(-20)$
\end{tabular}

hexosamine concentration in serum declined soon after partial hepatectomy. In the present experiments, the hexosamine content in plasma proteins was also decreased at $12 \mathrm{~h}$. In addition, the sialic acid content of plasma proteins became significantly lower (Table 2).

\section{Discussion}

The synthesis of sialic acid was decreased in regenerating rat liver within $48 \mathrm{~h}$ after partial hepatectomy, and this can be explained by the lowered activities of UDP- $N$-acetylglucosamine 2epimerase and $N$-acylmannosamine kinase at $12 \mathrm{~h}$ after hepatectomy. Okubo et al. (1977) reported that the activity of UDP- $N$-acetylglucosamine 2epimerase in regenerating rat liver was higher than in controls at $24 \mathrm{~h}$ after partial hepatectomy, but decreased thereafter and became lower than in controls at 72 and $120 \mathrm{~h}$. They also showed that the concentration of CMP- $N$-acetylneuraminic acid decreased during the period from 24 to $120 \mathrm{~h}$ after partial hepatectomy. These observations, together with our results, suggest that a decrease of sialic acid synthesis is a characteristic common to rat liver at early periods of regeneration, though the pattern of the enzyme response to partial hepatectomy may vary according to the differences in the age of the rats or other experimental conditions.

The activities of UDP- $N$-acetylglucosamine 2epimerase and $N$-acyl-D-mannosamine kinase are extremely low in a variety of rat hepatomas and in foetal liver as compared with adult rat liver (Kikuchi et al., 1971), corresponding with our results of the changes of the enzyme activities at $12 \mathrm{~h}$ after partial hepatectomy. Possibly, the lowered activities of these two enzymes are intimately correlated with liver growth.

Sialyltransferase activities towards exogenous acceptors have been shown to increase significantly after partial hepatectomy (Serafini-Cessi, 1977:
Ip, 1979). But the enzyme activities towards endogenous acceptors are not changed significantly from 7 to $48 \mathrm{~h}$ after such treatment (Serafini-Cessi, 1977). Thus the decreased synthesis of CMP- $N$-acetylneuraminic acid may lower the addition of sialic acid to glycoproteins. During early periods of liver regeneration, the synthesis of plasma glycoproteins decreases (Okamoto \& Akamatsu, 1977; SerafiniCessi, 1976). The decreased sythesis of sialic acid in the liver was linked with the low level of proteinbound sialic acid in plasma. On the other hand, the level of protein-bound sialic acid in regenerating liver was not changed. Prolongation of the half-life of sialoglycoproteins in regenerating rat liver was reported by Tauber \& Reutter (1978). This may contribute to the maintenance of the amount of protein-bound sialic acid in the liver.

The decline of siaiic acid synthesis was most pronounced at $12 \mathrm{~h}$ after partial hepatectomy. This is thought to be the time immediately before the initiation of DNA synthesis in regenerating rat liver (Bresnick, 1971). It is interesting to study how the changes in sialic acid metabolism are related to other pre-replicative changes in the liver. For example, a decrease of the synthesis of CMP-Nacetylneuraminic acid can contribute to the increase of the CTP pool in regenerating liver (Bucher \& Swaffield, 1969).

\section{References}

Bresnick, E. (1971) Methods Cancer Res. 6. 347397

Bucher, N. L. R. \& Swaffield. M. N. (1969) Biochim. Biophy's. Acta 174, 491-502

Cardini, C. E. \& Leloir, L. F. (1957) J. Biol. Chem. 225, 317-324

Datta, A. (1970) Biochemistry 9, 3363-3370

Harms, E., Kreisel, W., Morris, H. P. \& Reutter, W. (1973) Eur. J. Biochem. 32. 254-262

Higgins, G. M. \& Anderson, R. M. (1931) Arch. Pathol. 12, 186-202

Ip. C. (1979) Biochim. Biophy's. Acta 583, 14-19

Kikuchi, K.. Kikuchi, H. \& Tsuiki, S. (1971) Biochim. Biophy's. Acta 252, 357-368

Kornfeld, S., Kornfeld, R.. Neufeld, E. F. \& O'Brien. P. J. (1964) Proc. Natl. Acad. Sci. U.S.A. 52. $371-379$

Kundig. W. \& Roseman. S. (1966) Methods Enzı'mol. 8. $195-200$

Larmo. A. L.. Teir. H. \& Rytömaa. T. (1962) Exp. Cell Res. 27, 95-99

Lowry. O. H., Rosebrough. N. J., Farr. A. L. \& Randall, R. J. (1951) J. Biol. Chem. 193. 265275

Molnar. J.. Robinson, G. B. \& Winzler, R. J. (1965) J. Biol. Chem. 240. 1882-1888

Okamoto. Y. \& Akamatsu. N. (1977) Biochim. Biophy's. Acta 498. 272-281

Okamoto, Y.. Ito. E. \& Akamatsu. N. (1978) Bio chim. Bioph's. Acta 542. 21-27 
Okubo, H., Shibata, K., Ishibashi, H. \& Yanase, T. (1977) Proc. Soc. Exp. Biol. Med. 155, 152156

Reissig, J. L., Strominger, J. L. \& Leloir, L. F. (1955) J. Biol. Chem. 217, 959-966

Serafini-Cessi, F. (1976) Biochem. J. 158, 153-155

Serafini-Cessi, F. (1977) Biochem. J. 166, 381-386
Spivak, C. T. \& Roseman, S. (1966) Methods Enzymol. 9, 612-615

Tauber, R. \& Reutter, W. (1978) FEBS Lett. 87, $135-138$

Warren, L. (1959) J. Biol. Chem. 234, 1971-1975

Watson, D., Jourdian, G. W. \& Roseman, S. (1966) Methods Enzymol. 8, 201-205 